\title{
Language Contact, Use and Attitudes among the Chaldo-Assyrians of Baghdad, Iraq: A Sociolinguistic Study
}

\author{
Bader S. Dweik, Tiba A. Al-Obaidi \\ Middle East University, Faculty of Arts and Sciences, Department of English Language and Literature \\ drdweik@yahoo.com \\ Middle East University, Faculty of Arts and Sciences, Department of English Language and Literature \\ tebaabdelkarim@yahoo.com
}

\begin{abstract}
This study aimed at investigating the language situation among the Chaldo-Assyrians in Baghdad. The study attempted to answer the following questions: In what domains do the Chaldo-Assyrians of Baghdad use Syriac and Arabic? What are their attitudes towards both languages? To achieve the goal of this study, the researchers selected a sample that consisted of (135) Chaldo-Assyrians of different age, gender and educational background. The instruments used in this study were interviews and a questionnaire which comprised two different areas: domains of language use and language attitudes. The researchers concluded that the Chaldo-Assyrians in Baghdad used Syriac in different domains mainly at home, in religious settings and in their inner speech; and used it side by side with Arabic in many other social domains such as neighborhood, place of work, media and other public places. The study revealed that the attitudes of the ChaldoAssyrians towards Syriac and Arabic were highly positive. Finally, the researchers recommended conducting similar studies on other ethnic groups in Baghdad like Turkumans, Kurds, Armenians and Sabians.
\end{abstract}

\section{Indexing terms/Keywords}

Language Contact; Use; Attitudes; Chaldo-Assyrians; Iraq.

\section{Academic Discipline And Sub-Disciplines}

Sociology, sociolinguistics

\section{SUBJECT CLASSIFICATION}

Languages in contact

\section{TYPE (METHOD/APPROACH)}

A combination of qualitative and quantitative research design, Community profile, survey, interviews.

\section{Council for Innovative Research}

\section{Journal: Journal of Advances in Linguistics}

\author{
Vol 3, No. 3 \\ editor@cirworld.com \\ www.cirjal.com, www.cirworld.com
}




\section{INTRODUCTION}

One of the central concerns of sociolinguists has been the situation of indigenous languages which for various reasons are in danger of disappearing from usage either globally or locally.

Ethnic languages are important components to many minority ethnic groups because they are symbols that identify a person with certain ethnic features. Spolsky (1998) referred to the role of language in establishing social identity and said that "most ethnic groups believe that their language is the best medium for preserving and expressing their traditions" (p.57). Many studies were conducted to investigate the languages of indigenous minority groups in many places around the world. Researchers scrutinized ethnic loyalty and described the usage and attitude of ethnic minorities towards languages such as Quechua language in Peru, (Von Gleich \& Wolck, 2004), and Arabic language in Palestine (Dweik and Kittaneh, 2011) and the Assyrian language in the diaspora (Odisho ,1999 and McClure , 2001).

There is evidence from a number of sociolinguistic studies performed all over the world that when languages are in contact, the powerful language dominates and the other language may be replaced or the two languages are used side by side in $a$ diglossic relationship (Fishman, 1989).

\section{The Chaldo-Assyrians of Iraq: Who Are They?}

The Chaldo-Assyrians are the descendants of the ancient Aramean-speaking population of northern Mesopotamia, which adopted Christianity in the first century A.D. and pioneered this religion in the area. Currently Chaldo-Assyrian communities exist almost in every Near Eastern country including Iran, in major cities of Iraq (Mosul, Duhok, and Baghdad), Syria, Turkey, and Armenia. Furthermore, the name Assyrians according to Nissan (2002) embodies the collective ethnicity of Aramean-speaking Christians and includes the primary religious groups under one Assyrian nation which existed long time before Christianity.

According to Stafford (2006) Assyrians are " Semitic people who had migrated from southern Mesopotamia after the fall of Ur...and their power was felt all over the Middle East and Near East...but the heart of their country was the Tigris plain between Nineveh and Assur" (p. 15). Assyria which is a kingdom in northern Mesopotamia (modern Iraq) began around $1350 \mathrm{BC}$. At its height (730-650 BC), the Assyrian empire controlled the Middle East from the Gulf to Egypt, but it collapsed in $612 \mathrm{BC}$.

\section{Objectives of the Study}

This study aims to examine how the Chaldo-Assyrians of Baghdad use Neo-Aramaic (Syriac) and Arabic in different domains and to explore their attitudes towards both languages.

\section{Questions of the Study}

The study attempts to answer the following questions:

1- In what domains do the Chaldo-Assyrians of Baghdad use Neo-Aramaic (Syriac) and Arabic?

2- What are their attitudes towards both languages?

\section{Significance of the Study}

Although there are a lot of investigations that have dealt with the minority languages in the Middle East, few studies have focused on the status of the aboriginal languages when they are in contact with a majority language such as Arabic in Baghdad. Although there are studies that have dealt with the Assyrian minority language in the diaspora, few have focused on the status of the Chaldo-Assyrians in the homeland precisely in Baghdad-Iraq. This study is expected to help other researchers who want to conduct studies about similar topics. In addition, this work may be very helpful for teachers and parents since it may encourage them to play an effective role in enhancing the ethnic identity among younger generations.

\section{REVIEW OF THEORETICAL LITERATURE}

Language contact refers to the use of two or more languages alternately by the same persons, and the individuals who use language are thus the focus of contact.

Winford (2003) examined different types of language contact and claimed that the different outcomes stem from different social situations. In other words, language contact phenomena can be categorized and better understood by considering the situations under which they were formed. He named different contact outcomes such as language maintenance, language shift, and language creation and showed that different circumstances and differing levels of contact intensity produced slightly different linguistic results within these general outcomes.

Thomason (2001) defined language contact simply as "the use of more than one language in the same place at the same time" (P. 1). She stated that the most common result of language contact is a change in languages in a way that one 
language may affect the other. She has concluded that languages in contact result in a hierarchical set of classifications that start from contact-induced language change, extreme mixture of language (represented by pidgin, creole, and bilingual mixed languages), and language death.

Hamers and Blanc (1999) discussed the idea of sociolinguistic variations in language contact situations. They stated that:

in a situation of language contact the status of each language varies on the one hand as a function of the nature of inter group relations, in particular power relations and the values and norms attached to these, and on the other hand as a function of the perceptions that speakers form of these relations, their values and norms (p.172).

Wright, Holmes and Kelly (1995) discussed the relationship between languages in contact and conflict. Language conflict can occur anywhere there is language contact, chiefly in multilingual communities. Conflict can be viewed as a form of contact or as a complementary model to the language contact model because "language conflict arises from the confrontation of differing standards, values, attitude structures and strongly influences identity image..." (p.67). They stated that:

\begin{abstract}
Most contact between ethnic groups does not occur in context of peaceful, harmoniously coexisting communities. Rather, contact typically takes place in a context of varying degrees of tension, resentment and differences in opinion (p.65).
\end{abstract}

Fishman (1989) presented three resolutions considered as the outcome of languages in contact. He stated that when the immigrant language, the "intrusive" language, comes into contact with the host language "the indigenous" language will result in three possibilities. The first possibility is when the indigenous language interacts with the intrusive language then the intrusive language is lost. The second possibility or resolution happens when an indigenous language interacts with an intrusive language; here the indigenous is lost. The third and the final resolution is that when an indigenous language comes into contact with intrusive language; here both languages are preserved or maintained. The last resolution will be the theoretical foundation of the current study where the indigenous language (i.e. Syriac) is used side by side with the intrusive languages mainly the current dominant language (i.e. Arabic) through its long history

Weinreich (1974) discussed the effect of bilingualism in a language contact situation referring to the linguistic and extralinguistic factors that may result in changing the languages of the bilingual persons. Such exrta-linguistic factors are represented by speaker's proficiency in each language, manner of learning each language, attitudes towards each, and his ability to keep two languages separate. He also referred to the role of socio-cultural setting of language contact saying that "when a language-contact situation is examined in detail, the interrelation of socio-cultural conditions and linguistic phenomena is apparent" (p.83). He cited some factors that play a major role in the choice of bilingual groups in making the language dominant for them, determined by social and linguistic habits, such factors are the usefulness of a language, its role in social advance, and its literary cultural value.

\title{
REVIEW OF EMPIRICAL STUDIES
}

Dweik (1986) conducted a study among three linguistic minorities in Jerusalem (i.e. the Armenians, the Assyrians and the Greeks). He examined the situation of these languages after being in contact with (Arabic, English and Hebrew). It was found that some extra-linguistic factors determined the language maintenance among these ethnic groups. Diverse methods were used by the researcher in collecting data such as observing individuals in the community and interviewing key personalities. The results showed that "the three linguistic minorities maintain their ethnic languages and cultures very highly" (p.60).

Von Gleich and Wolck (1994) explored language contact situations and examined the use and attitudes of languages among the indigenous people in Peru towards their mother tongue (Quechua) and towards majority language (Spanish). They found that the two languages were used side by side in the same domains. The usage of both languages side by side helped to slow the erosion of the minority language, promoted its survival, and produced a more stable type of bilingualism. They found too, that the sample survey of attitudes towards the use of Quechua showed that whereas monolingual Spanish speakers generally are not interested in maintaining the country's second language, an increasing portion of Quechua speakers would like to see Quechua taught side by side with Spanish. They concluded that in the linguistic contact and conflict between Quechua and Spanish in Peru, a considerable opening of domains long reserved for Spanish to their treatment in Quechua, as well as in Spanish, has more than offset the reduction in Quechua monolingualism in the region.

Vakhtin (1998) examined Siberian indigenous languages which were in close contact with each other for centuries under the title Endangered Languages in Northeast Siberia: Siberian Yupik and other languages of Chukotka. He presented two-fold perspectives on the indigenous languages of Chukotka: an insider perspective which is the researcher's point of view and an outsider perspective that is made by several interviews with the members of indigenous community to document the condition of the languages of the indigenous groups. In his study he found that most of the indigenous groups have lost their native languages especially among the young generation and shifted to the Russian language, the dominant and official language because as he said they "demonstrated strong Russian influence, deep traces of language contact in their lexicons, grammars and even phonology" (p. 167) that they were going into the process of language loss. He stated that in spite of the language abandonment among the indigenous groups, they believed that their native languages are the symbol of their ethnic identity and had a positive attitude towards their mother tongue.

Friðriksson (2008) investigated language stability versus change in the conservative language communities and he took the Icelandic language as one of them to examine whether or not the language can still be characterized as stable under the 
ongoing changes in modern Icelandic. In his study, he presented a historical background of the Iceland and how the community could preserve their language even after several political developments and despite the diseases that caused lots of death and immigration to other areas. He made a number of interviews as a means of collecting data to identify the conditions which support this stability with a total of 108 informants chosen on the basis of a set of social criteria. All informants were interviewed to obtain information on their social background, the structure of their social networks, and on their attitudes towards and awareness of the supposed changes.

The study found that language use indicated that Icelandic can still be characterized as a stable language. It was found that the informants were in high level of awareness of the alleged changes and high level of negativity towards them. Furthermore, the researcher indicated to other results that showed some factors which helped preserving the language, such as "strong linguistic nationalism and a stability-oriented language policy. These were instrumental in creating the sociolinguistic conditions in Iceland which supported language stability" (p.5).

\section{METHODOLOGY}

The targeted population of this study consisted of all Chaldo-Assyrians who live in Baghdad. A sample of 150 participants was selected but it had been 135 due to the availability of the participants. The participants were chosen purposively on the basis of the convenience availability and constructed to serve a very specific purpose for this study which is to explore the sociolinguistic situation of the Chaldo-Assyrian community in Baghdad. Particularly, to investigate the domains in which both languages (Syriac and Arabic) are used, the factors that help using both languages, and their attitudes towards both languages.

The sample included a wide range of several important demographic variables i.e. different age, gender, occupations, and marital status besides linguistic and community background. It consists of (53) males and (82) females of whom (64) were single, (44) married, (11) engaged, (2) divorced and (14) widows.

\section{Instruments of the Study}

The instruments used in this study were, informal interviews and a questionnaire. The researcher used in-group assistance method following Bickerton's method (1971) who suggested that using the method of readily obtainable group of people would enable the researcher to gain fruitful results and would overcome some problems. For instance, some of the respondents would not give personal information or any other thing to the strangers. Thus those assistants of in-group, he claimed, are part of the speech community and considered an important component for the sample of the study.

One of the assistants was a friend who had close contact with senior Chaldo-Assyrian figures namely members of Assyrian Democratic Movement (ADM), an Assyrian political movement located in Zayoona district in Baghdad. In fact, advance appointments were scheduled with one of those members to explain what was required and then to gain their trust. Actually ADM was the second main assistant in distributing the questionnaires and collecting the data. Also, the Assyrian churches helped in distributing the questionnaires. The head of those churches introduced the researcher to its workers and visitors and allowed her to make contacts and interviews with them.

\section{Interviews}

This tool is considered one of the most important ways to compile information about community background. The researchers selected a limited number of key personalities in the community to provide the required information about the community (Butler and DePhelps, 1994). The, interviews gave the researchers an opportunity to get more detailed information and get more validity and credibility of the given information by observing the way participants' response and reaction through (their tone of voice, hesitations, facial expressions, etc..). Interviews were conducted informally using openended questions and were coded and transcribed. But before that, the researchers contacted their friends who have direct relations with those figures to arrange appointments with them. Appointments were set in advance after short conversations over the phone. In most cases the researchers used "open-ended interviews". Taking into consideration that the time and place of the interview were convenient to the participants. The researchers introduced themselves and explained the reason of the interview and they were assertive and relaxed. The interviewees were very welcoming and hospitable and provided the researchers enthusiastically with much information about the Chaldo-Assyrian community. The researchers asked them about the estimate number of the Chaldo-Assyrians in Baghdad, their residential distributions, their ethnic schools and Churches locations, their economic, social and linguistic status and their social activities. Other wide range of detailed questions was raised within the conversation contexts which in turn helped the researcher to compile extra data on the community.

Moreover, other members of Chaldo-Assyrian community were interviewed informally. In fact, one of the interviews was made with a teacher in one of Syriac-teaching schools (The Syriac Orthodox Primary School) in Zayoona district by phonecall. He was asked about where and when he uses Syriac and Arabic, his attitudes towards both languages and the factors that help him using both. Furthermore, the researchers interviewed two heads of churches; one of which was located in Karrada district and the other one in Hay-Sumer (Sumer quarter). Several structured interviews with the worshippers and workers of the churches were made and their answers were transcribed.

\section{The Sociolinguistic Questionnaire}

Three groups of assistants served the researchers in distributing, handing in and collecting the copies of the questionnaire. The first was a person who lived in a mixed Arab Chaldo-Assyrian neighborhood and had many Chaldo-Assyrian friends and 
neighbors. The second were the heads of churches and some of social leaders. The third were the members of ADM (Assyrian Democratic Movement) a political movement which had many contacts with Chaldo-Assyrians and was considered by the majority as a significant representative of Chaldo-Assyrians community.

The researchers made use of the questionnaires used by Fishman (1966), Dweik (2000), Al-Khatib (2001), Kittaneh (2009), Al-Nahar (2009) and Nofal (2011). They adapted and modified them to suit the community under investigation. The questionnaire was validated and tested before it was administered to a sample of respondents from Chaldo-Assyrian in Baghdad. The questionnaire consisted of four parts. A covering letter that explained the purpose of the questionnaire and how to fill it up was attached to it. The questionnaire started with a demographic, social and linguistic background section which described the social and linguistic background of the participants, their residential distributions and their social activities.

The second part of the questionnaire aimed at finding out the domains in which the respondents use each language. This part of the questionnaire gave five options to the respondents to choose one of the following categories:

\section{1-Syriac Only 2- Mostly Syriac 3-Syriac and Arabic 4- Mostly Arabic 5-Arabic Only}

Six domains of language use were suggested including the home domain, the neighborhood, workplace, media, religion, emotional self-expressions and other different situations. This section consisted of thirty-four items. Four items focused on language use in the home domain with different family members such as father, mother, relatives, etc... in different occasions. The neighborhood was covered with four items focusing on language use with neighbors, friends, etc. The workplace part contained five items which were centered on the use of language at work place with different people such as work-mates, boss, etc. and in different activities like giving oral instructions. A set of four items was assigned to the use of language in media such as TV programmes and radio programmes. The following items focused on asking about language and religion (e.g. the language used with friend at the churches, when praying, etc.). The last section consisted of five items which dealt with the use of language in inner speech and unconscious situations such as dreaming, expressing happiness, being angry, etc... In this section, respondents were asked to check off the language(s) they usually use when talking to different people at different places on different topics.

The third part of the questionnaire aimed at exploring the respondents' personal attitudes and feelings towards the Syriac ethnic language and Arabic. In this section the respondents were asked to read the statements and choose one of the fivepoint scale answers used in this part of attitudes to reveal their personal opinion towards the given languages. It consisted of twenty seven statements and here are the five options given to the respondents after reading each statement:
1- Strongly agree
2- Agree
3- Undecided
4- Disagree
5- Strongly disagree

\section{Validity and Reliability}

Validity of the questionnaire was obtained by distributing the questionnaire to a panel of experts in the field of linguistics to examine its suitability and appropriateness. The researchers formed the questionnaire in its final shape after making some modifications to some items according to the notes and recommendations of the jurors. It was also tested for reliability by applying the test- retest measure. The researchers distributed the designed questionnaire among ten people who were not from the sample of the study and asked them whether the questions were clear and informative. The test was administrated in the second week of August in 2012/2013. After one week, the questionnaire was distributed again to the sample of the study. Then, the researchers collected and analyzed data in order to get the most accurate results which are presented in tables. Percentages of responses are calculated by using the SPSS system.

\section{RESULTS AND DISCUSSION}

The study questions and their results are presented below in tables and calculated in percentages. The two research questions are:

1- In what domains do the Chaldo-Assyrians in Baghdad use Syriac and Arabic?

2- What are their attitudes towards both languages?

\section{Results of Question One}

This question examines the domains of language use of both languages Syriac and Arabic. The domains in which languages are used including home, neighborhood, workplace, place of worship (church), media, and other social situations were under investigation that covered six main questions. These questions examine the components of domain namely the person (to whom the respondent is speaking) and place (where the conversation is taken place) which are important for deciding the factors that contribute to the choice of language. Language usage ratings are made on a fivepoint scale ranging from only Syriac; mostly Syriac; both Syriac and Arabic; mostly Arabic; and only Arabic.

Results reported in Table 1 below show the language that respondents use at home with family members. The questions are intended to reveal whether there are consistent responses when different family members were addressed. Results show that the majority of the Chaldo-Assyrians tend to use Syriac at home with their family members and relatives; $99 \%$ of them use it with their fathers and mothers. The same ratings go for the usage of Syriac among other members of the family like siblings, grandfather, and grandmother.

It is clear from this table that the overwhelming majority of the respondents $97 \%$ use Syriac with their siblings; $90 \%$ of them use it with their grandfathers, $92 \%$ of them use it with their grandmothers and only $2 \%$ of them use both Syriac and 
Arabic with their grandfathers and grandmothers. Also $99 \%$ of them use it with their relatives when they talk to them on the phone and $98 \%$ of them use it when talking to them face-to-face. Moreover, the results show that $97 \%$ of the respondents use Syriac with their relatives in family meetings and only 3\% of them use both Arabic and Syriac in such meetings.

Table 1: Language Use at Home

\begin{tabular}{|c|c|c|c|c|c|c|c|}
\hline Questions & $\begin{array}{c}\text { Syriac } \\
\text { only } \\
\%\end{array}$ & $\begin{array}{c}\text { Mostly } \\
\text { Syriac } \\
\%\end{array}$ & $\begin{array}{l}\text { Syriac } \\
\& \\
\text { Arabic } \\
\% \\
\end{array}$ & $\begin{array}{c}\text { Mostly } \\
\text { Arabic } \\
\% \\
\end{array}$ & $\begin{array}{c}\text { Arabic } \\
\text { only } \\
\%\end{array}$ & $\begin{array}{c}\mathrm{NR}^{*} \\
\%\end{array}$ & $\begin{array}{l}\text { Total } \\
100 \%\end{array}$ \\
\hline \multicolumn{8}{|l|}{$\begin{array}{l}\text { 1-Language use at home among } \\
\text { family Members and relatives: }\end{array}$} \\
\hline $\begin{array}{l}\text { What language do you use with } \\
\text { your father? }\end{array}$ & 97 & 2 & 1 & - & - & - & 100 \\
\hline Your mother & 97 & 2 & 1 & - & - & - & 100 \\
\hline Your siblings & 95 & 2 & 3 & - & - & - & 100 \\
\hline Your grandfather & 90 & - & 2 & - & - & 8 & 100 \\
\hline Your grandmother & 92 & - & 2 & - & - & 6 & 100 \\
\hline $\begin{array}{l}\text { What language do you use when } \\
\text { you make a phone call with one of } \\
\text { the members of the family? }\end{array}$ & 95 & 4 & 1 & - & - & - & 100 \\
\hline $\begin{array}{l}\text { What language do you use with } \\
\text { your other relatives when you talk } \\
\text { to them face to face? }\end{array}$ & 97 & 1 & 2 & - & - & - & 100 \\
\hline $\begin{array}{l}\text { What language do you use at } \\
\text { family meetings? }\end{array}$ & 97 & . & 3 & - & - & - & 100 \\
\hline
\end{tabular}

*Key: NR=No Response

Results reported in Table 2 below indicate that almost the majority of respondents use both Syriac and Arabic in the neighborhood domain.

Table 2: Language Use in the Neighborhood

\begin{tabular}{|l|c|c|c|c|c|c|c|}
\hline \multicolumn{1}{|c|}{ Questions } & $\begin{array}{c}\text { Syriac } \\
\text { only } \\
\%\end{array}$ & $\begin{array}{c}\text { Mostly } \\
\text { Syriac } \\
\%\end{array}$ & $\begin{array}{c}\text { Syriac \& } \\
\text { Arabic } \\
\%\end{array}$ & $\begin{array}{c}\text { Mostly } \\
\text { Arabic } \\
\%\end{array}$ & $\begin{array}{c}\text { Arabic } \\
\text { only } \\
\%\end{array}$ & $\begin{array}{c}\text { NR }^{*} \\
\%\end{array}$ & $\begin{array}{c}\text { Total } \\
100 \%\end{array}$ \\
\hline $\begin{array}{l}\text { 2-Language in the } \\
\text { neighborhood: }\end{array}$ & 20 & 4 & 48 & 16 & 12 & - & 100 \\
\hline $\begin{array}{l}\text { What language do you use when } \\
\text { you meet friends in the } \\
\text { neighborhood? }\end{array}$ & 12 & 3 & 15 & 29 & 41 & - & 100 \\
\hline $\begin{array}{l}\text { What language do you use when } \\
\text { you want to buy vegetables from } \\
\text { the greengrocer at the } \\
\text { neighborhood? }\end{array}$ & 23 & 2 & 42 & 20 & 13 & - & 100 \\
\hline $\begin{array}{l}\text { What language do you use when } \\
\text { you use your mobile in making a } \\
\text { phone call in the neighborhood? }\end{array}$ & 23 & & & & \\
\hline
\end{tabular}

*Key: NR=No Response

It shows that $48 \%$ of the respondents reported using both Syriac and Arabic when talking to their friends in the neighborhood. These respondents live in the Chaldo-Assyrian congregational neighborhood. The table also shows that $42 \%$ of the respondents use both languages when they make phone calls in their neighborhood but when they are asked what language they use when buying vegetables from the greengrocer $70 \%$ of them said that they use Arabic. Probably these latter responses indicate that the respondents are in more contact with Arabs compared with their Chaldo-Assyrian peers. It is likely that the responses in Table 5 indicate that Syriac and Arabic are used side by side in the neighborhood domain. 
Results reported in Table 3 below indicate that the two languages are used together at the work domain. It is clear that $45 \%$ of the respondents use both Syriac and Arabic when they talk to their fellow workers at work. Perhaps these respondents work in mixed Arab Chaldo-Assyrian workplaces.

Table 3: Language Use at Workplace

\begin{tabular}{|c|c|c|c|c|c|c|c|}
\hline Questions & $\begin{array}{c}\text { Syriac } \\
\text { only } \\
\%\end{array}$ & $\begin{array}{c}\text { Mostly } \\
\text { Syriac \% }\end{array}$ & $\begin{array}{c}\text { Syriac \& } \\
\text { Arabic } \\
\%\end{array}$ & $\begin{array}{c}\text { Mostly } \\
\text { Arabic } \\
\%\end{array}$ & $\begin{array}{c}\text { Arabic } \\
\text { only } \\
\%\end{array}$ & $\begin{array}{c}\mathbf{N R}^{*} \\
\%\end{array}$ & $\begin{array}{l}\text { Total } \\
100 \%\end{array}$ \\
\hline $\begin{array}{l}\text { 3-Language at workplace: } \\
\text { What language do you use with } \\
\text { your fellow workers at work? }\end{array}$ & 10 & 5 & 45 & 24 & 7 & 8 & 100 \\
\hline $\begin{array}{l}\text { What language do you use at } \\
\text { work when you discuss } \\
\text { business or technical matters } \\
\text { with your boss? }\end{array}$ & 10 & 11 & 39 & 12 & 20 & 8 & 100 \\
\hline $\begin{array}{l}\text { What language do you use at } \\
\text { work when you discuss } \\
\text { business or technical matters } \\
\text { with your fellow workers? }\end{array}$ & 10 & 4 & 40 & 20 & 16 & 8 & 100 \\
\hline $\begin{array}{l}\text { What language do you use at } \\
\text { work when you discuss general } \\
\text { topics (weather, sports, } \\
\text { politics) with your fellow } \\
\text { workers? }\end{array}$ & 15 & 2 & 41 & 11 & 23 & 8 & 100 \\
\hline $\begin{array}{l}\text { What language do you use at } \\
\text { work when you give oral } \\
\text { instructions at your workplace? }\end{array}$ & 13 & 7 & 38 & 20 & 14 & 8 & 100 \\
\hline
\end{tabular}

Fifteen percent of the respondents reported that they use Syriac with their fellow workers and $31 \%$ of the respondents use Arabic in their workplaces as probably they use it with their Arab workers in governmental and private institutions.

Furthermore, results reported in Table 3 above indicate that $21 \%$ of the respondents use Syriac with their bosses when they talk about business or technical matters; those who work in their ethnic institutions and schools, while $39 \%$ of them use both languages; those who worked in mixed Arab Chaldo-Assyrian workplaces. Arabic is used by $22 \%$ of the respondents; those who work with Arab fellow workers and use it with them.

When responding to the question about the language used in discussing business and techniqual matters with their fellow workers, $14 \%$ reported that they use Syriac and $40 \%$ reported that they use both languages and $36 \%$ reported that they use Arabic; those respondents work in mixed Arab Chaldo-Assyrians in different institutional workplaces. On the other hand, when responding to the question about the language used in discussing general topics such as weather or sports, $41 \%$ reported that they use both Syriac and Arabic , 36\% reported that they use Arabic, and only $17 \%$ of them use Syriac; those who work in mixed Arab Chaldo-Assyrian workplaces.

Results reported in Table 3 also indicate that $38 \%$ of the respondents use both Syriac and Arabic in giving oral instructions or directions; $34 \%$ of them reported that they use Arabic which is a close rate to the usage of both languages by the respondents, and $20 \%$ of the respondents reported that they use Syriac. Respondents, who are between 10 to 19 and those who are unemployed comprise $8 \%$ of the respondents, did not respond to this section and thus they comprise $8 \%$ of the total responses.

Results reported in Table 4 below show language use in the domain of religion (at Church). The questions focus on the language that the respondents use when they pray, and practice their worships, and at religious meetings. The questions aim to test a variety of religious interactions where persons, topics or locals are involved. Table 4 shows that Syriac is dominant in this domain.

Similarly, $93 \%$ of them report that they use it with the celebrant and priest at church and only $7 \%$ of them use both languages. Moreover, $85 \%$ of them use it at religious meetings outside churches and $15 \%$ of them use both languages Syriac and Arabic. These results are supported with the assertion of the respondents themselves that they use mostly Syriac at churches because it is highly attached to their religion Christianity. 
Table 4: Language and Religion

\begin{tabular}{|c|c|c|c|c|c|c|c|}
\hline Questions & $\begin{array}{l}\text { Syriac } \\
\text { only } \\
\%\end{array}$ & $\begin{array}{l}\text { Mostly } \\
\text { Syriac } \\
\%\end{array}$ & $\begin{array}{c}\text { Syriac \& } \\
\text { Arabic } \\
\%\end{array}$ & $\begin{array}{l}\text { Mostly } \\
\text { Arabic } \\
\%\end{array}$ & $\begin{array}{c}\text { Arabic } \\
\text { only } \\
\%\end{array}$ & $\begin{array}{c}\mathrm{NR}^{\star} \\
\%\end{array}$ & $\begin{array}{l}\text { Total } \\
100 \%\end{array}$ \\
\hline \multicolumn{8}{|l|}{ 4- Language and religion: } \\
\hline $\begin{array}{l}\text { What language do you use When you } \\
\text { supplicate and pray at church? }\end{array}$ & 72 & 21 & 7 & - & - & - & 100 \\
\hline $\begin{array}{l}\text { What language do you use when you } \\
\text { speak with the celebrantlpriest at } \\
\text { church? }\end{array}$ & 70 & 23 & 7 & - & - & - & 100 \\
\hline $\begin{array}{l}\text { What language do you use when you } \\
\text { speak with the fellow worshipers at } \\
\text { church? }\end{array}$ & 77 & 20 & 3 & - & - & - & 100 \\
\hline $\begin{array}{l}\text { What language do you use at religious } \\
\text { meetings outside your place of } \\
\text { worship? }\end{array}$ & 60 & 25 & 15 & - & - & - & 100 \\
\hline
\end{tabular}

*Key: NR=No Response

Table 5: Language and Media

\begin{tabular}{|c|c|c|c|c|c|c|c|}
\hline Questions & $\begin{array}{l}\text { Syriac } \\
\text { only \% }\end{array}$ & $\begin{array}{l}\text { Mostly } \\
\text { Syriac \% }\end{array}$ & $\begin{array}{c}\text { Syriac \& } \\
\text { Arabic } \\
\%\end{array}$ & $\begin{array}{l}\text { Mostly } \\
\text { Arabic } \\
\%\end{array}$ & $\begin{array}{l}\text { Arabic } \\
\text { only } \%\end{array}$ & $\mathbf{N R} * \%$ & $\begin{array}{l}\text { Total } \\
100 \%\end{array}$ \\
\hline 5-Language and media & & & & & & & \\
\hline $\begin{array}{l}\text { What language do you choose } \\
\text { when you listen to radio } \\
\text { programs? }\end{array}$ & 4 & 17 & 48 & 20 & 11 & - & 100 \\
\hline $\begin{array}{l}\text { What is your favorite language } \\
\text { for T.V entertainment? }\end{array}$ & 14 & 19 & 39 & 20 & 8 & - & 100 \\
\hline
\end{tabular}

*Key: NR=No Response

Table 5 above shows that the highest percentage rate, reported by the participants indicates that both languages Syriac and Arabic are used when they listen to Radio programs. Also the responses indicate that $21 \%$ of the respondents favor Syriac when they listen to radio programs while 31\% of them favor Arabic. Furthermore $39 \%$ of them favor both languages Syriac and Arabic, only $33 \%$ of them favor Syriac, and $28 \%$ of them favor Arabic.

Results reported in Table 6 below examine language use when the participants are in other situations: when happy, angry, in a hurry and when dreaming.

Results indicate that the categories "only and mostly Syriac" are chosen by the majority of the Chaldo-Assyrians in response for their situations. It is clear that a high percentage of the respondents $69 \%$ report using Syriac when they express their happiness, only $8 \%$ of them use Arabic and $23 \%$ of them use both Syriac and Arabic in this situation.

In response to Question 2 in Table 6 regarding the stress, anger, and confusion situations, the response rates of the category "only and mostly Syriac" is the highest one among other categories which is about $64 \%$ responses while $26 \%$ of the respondents report that they use both Syriac and Arabic and only $10 \%$ use Arabic in these situations. Moreover, when the respondents were asked what language they use when they are in a hurry, the majority of them $71 \%$ report that they use Syriac while $22 \%$ of them use both languages and only $7 \%$ use Arabic. Regarding the situation of "dreaming", $72 \%$ of the respondents report using Syriac in their dreams, 22\% use both Syriac and Arabic, and only 6\% use Arabic. 
Table 6: Language Use and Emotional Self-Expression

\begin{tabular}{|c|c|c|c|c|c|c|c|}
\hline Questions & $\begin{array}{c}\text { Syriac } \\
\text { only } \\
\%\end{array}$ & $\begin{array}{c}\text { Mostly } \\
\text { Syriac } \\
\%\end{array}$ & $\begin{array}{c}\text { Syriac\& } \\
\text { Arabic \% }\end{array}$ & $\begin{array}{c}\text { Mostly } \\
\text { Arabic } \\
\%\end{array}$ & $\begin{array}{l}\text { Arabic } \\
\text { only \% }\end{array}$ & $\begin{array}{c}\mathrm{NR}^{*} \\
\%\end{array}$ & $\begin{array}{l}\text { Total } \\
100 \%\end{array}$ \\
\hline \multicolumn{8}{|l|}{$\begin{array}{l}\text { 6- Language and emotional self- } \\
\text { expression }\end{array}$} \\
\hline $\begin{array}{l}\text { Which language do you prefer } \\
1 \text {-to express your happiness? }\end{array}$ & 47 & 22 & 23 & 8 & - & - & 100 \\
\hline $\begin{array}{l}\text { 2-to use when you are angry, } \\
\text { stressed and confused? }\end{array}$ & 48 & 16 & 26 & 9 & 1 & - & 100 \\
\hline 3-to use when you are in a hurry? & 50 & 21 & 22 & 6 & 1 & - & 100 \\
\hline $\begin{array}{l}\text { 4-Which language is used } \\
\text { in your dreams? }\end{array}$ & 50 & 22 & 22 & 6 & - & - & 100 \\
\hline
\end{tabular}

\section{Results of Question Two}

This question deals with the respondents' attitudes towards both languages, i.e., Syriac and Arabic. Twenty seven questions ask the respondents about their views towards Syriac and Arabic in terms of beauty, usefulness, and preference. The questions also examine the importance of speaking Syriac and Arabic and the reason of using each language.

Results reported in Table 7 below show that the majority of the respondents, $90 \%$, consider Syriac to be the most beautiful language and $10 \%$ of them are undecided.

Results in Table 7 also show attitudes of respondents concerning the most prestigious language. Results indicate that $69 \%$ of the respondents consider that Syriac is prestigious language because it is traced back to the language of Jesus. However, $31 \%$ of the respondents are undecided.

In Table 7, results also show that the majority of the respondents $91 \%$ regard that Syriac language as the symbol of their Chaldo-Assyrian identity. A small number of them $9 \%$ were indecisive while $2 \%$ of the responses were empty. With regards to the preference of the usefulness of Syriac in comparison to Arabic, results show that $47 \%$ of the respondents consider Syriac to be more useful than Arabic, while $28 \%$ of the respondents are undecided and $17 \%$ of them disagree with the statement that say Syriac is more useful than Arabic.

Results reported in Table 7 indicate that $81 \%$ consider Syriac as their national language whereas $10 \%$ of them are undecided and only $3 \%$ do not agree.

Regarding the importance of teaching Syriacin all public schools, Table 7 shows that $82 \%$ of the respondents agree about this idea while $4 \%$ of them are indecisive and only $2 \%$ of the respondents do not agree. When the respondents are asked about the importance of using Syriac officially side by side with Arabic in all domains, results in Table 7 show that $63 \%$ of the respondents agree and $29 \%$ are indecisive and only $2 \%$ disagree.

Results reported in Table 10 also show that an overwhelming majority of the respondents $92 \%$ do not believe that Syriac is dying in their homes. Similarly, an overwhelming majority of the respondents $74 \%$ report that they disagree as to the death of Syriac in their community.

Results reported in Table 7 also show the views of the respondents regarding the Syriac as the language of their childhood, $91 \%$ agree and only $2 \%$ disagree. With regards to the importance of using Syriac in all domains, Table 7 reports that $60 \%$ of the respondents show their agreement with the idea, and $28 \%$ of the respondents are indecisive.

Table 7 also reports the opinions of the respondents towards the idea of using Syriac for instructions at schools. Half of the respondents $52 \%$ agree with this idea, $18 \%$ of them disagree and $20 \%$ are undecided. In response to the importance of using Syriac in churches and in religious meetings, results in Table 7 show that the majority of the respondents $97 \%$ agree because they believe that their ethnic language is associated with their religion. Similarly, results reported in Table 7 also assert that the overwhelming majority of the respondents $98 \%$ believe that Syriac is associated with the ChaldoAssyrian heritage and history. 
Table 7: Language Attitudes towards Syriac

\begin{tabular}{|c|c|c|c|c|c|c|c|}
\hline 1- Attitudes towards Syriac & $\begin{array}{l}\text { Strongly } \\
\text { Agree } \\
\%\end{array}$ & $\begin{array}{l}\text { Agree } \\
\%\end{array}$ & $\begin{array}{l}\text { Undecided } \\
\%\end{array}$ & $\begin{array}{l}\text { Disagree } \\
\%\end{array}$ & $\begin{array}{c}\text { Strongly } \\
\text { Disagree } \\
\% \\
\end{array}$ & $\begin{array}{c}\mathbf{N R}^{\star} \\
\%\end{array}$ & $\begin{array}{c}\text { Total } \\
100 \\
\%\end{array}$ \\
\hline is the most beautiful language. & 72 & 18 & 10 & - & - & - & 100 \\
\hline $\begin{array}{l}\text { is the most prestigious language } \\
\text { because it is considered as the } \\
\text { language that traced back to the } \\
\text { language of Jesus. }\end{array}$ & 49 & 20 & 31 & - & - & - & 100 \\
\hline $\begin{array}{l}\text { is the symbol of my Chaldo-Assyrian } \\
\text { identity. }\end{array}$ & 62 & 29 & 9 & - & - & 2 & \\
\hline is more useful than Arabic. & 38 & 9 & 28 & 17 & - & 8 & 100 \\
\hline is my national language. & 53 & 28 & 10 & 3 & - & 6 & 100 \\
\hline must be taught in all public schools. & 50 & 32 & 4 & 2 & - & 12 & 100 \\
\hline $\begin{array}{l}\text { must be used officially side by side } \\
\text { with Arabic in all domains. }\end{array}$ & 40 & 23 & 29 & 2 & - & 6 & 100 \\
\hline is dying in my house. & - & - & 8 & 33 & 59 & - & 100 \\
\hline is dying in my community. & 2 & 1 & 18 & 32 & 42 & 5 & 100 \\
\hline is the language of my childhood. & 67 & 24 & 1 & 2 & - & 6 & 100 \\
\hline is important to be used in all domains. & 46 & 14 & 28 & - & - & 12 & 100 \\
\hline $\begin{array}{l}\text { should be used for instructions at } \\
\text { school. }\end{array}$ & 32 & 22 & 20 & 13 & 5 & 8 & 100 \\
\hline $\begin{array}{l}\text { must be used in Church and religious } \\
\text { activities or meetings. }\end{array}$ & 88 & 9 & & - & - & 3 & 100 \\
\hline $\begin{array}{l}\text { is associated with the Chaldo-Assyrian } \\
\text { heritage and history }\end{array}$ & 92 & 6 & - & - & - & 2 & 100 \\
\hline $\begin{array}{l}\text { is important that my children } \\
\text { communicate effectively in it. }\end{array}$ & 53 & 37 & 2 & - & - & 8 & 100 \\
\hline
\end{tabular}

*Key: $N R=$ No Response

Results reported in Table 7 show the respondents' attitudes towards Syriac concerning its importance to their children. The results show that a high percentage, $90 \%$, of the respondents agree because they regard it as the language of their identity religion, and heritage.

Table 7 shows the respondents' attitudes towards Arabic and investigates the Chaldo-Assyrians' impressions about using Arabic in different domains. With regards to the importance of speaking Arabic in all domains by the respondents, results reported in Table 8 show that $57 \%$ agree, $29 \%$ undecided and $13 \%$ disagree.

Moreover, results in Table 8 also report that $55 \%$ of the respondents prefer using Arabic for instruction at school. Other results indicate that $12 \%$ of the respondents disagree and $27 \%$ are undecided.

With regards to the usefulness of using Arabic more than Syriac, results reported in Table 8 show that $18 \%$ of the respondents disagree and that $30 \%$ of the respondents agree with this statement and $40 \%$ indecisive.

When the respondents are asked about their feelings towards Arabic as being a reflection of imperialism, results in Table 8 show that $52 \%$ disagree, $30 \%$ undecided and $14 \%$ agree.

Table 8 shows the views of the respondents towards the importance of learning and using Arabic everywhere since it is the official language of the state. It shows that $49 \%$ agree, $15 \%$ undecided, $18 \%$ disagree and $18 \%$ give no answer

With regards to the statement that examines the reflections of the respondents about the concept that said Arabic is the prestigious language in the State so it is important to be learned, results indicate that $46 \%$ of the respondents express agreement, $37 \%$ indecisive and only $7 \%$ disagree. Ten percent give no answer.

Results reported in Table 8 which show the necessity of having knowledge in Arabic by the Chaldo-Assyrians in order to have jobs indicate that the majority of the respondent $83 \%$ agree, only $1 \%$ of the respondents disagree and $4 \%$ of them 
undecided. Moreover, this table indicates that $12 \%$ from the total responses are empty. Additionally, when the respondents are asked about the possibility that having knowledge in Arabic makes them get advanced professionally, the results in Table 8 report that $53 \%$ of the respondent agree, $9 \%$ disagree and $30 \%$ indecisive.

Table 8: Language Attitudes towards Arabic

\begin{tabular}{|c|c|c|c|c|c|c|c|}
\hline 2- Attitudes towards Arabic & $\begin{array}{l}\text { Strongly } \\
\text { Agree } \\
\%\end{array}$ & $\underset{\%}{\text { Agree }}$ & $\begin{array}{l}\text { Undecided } \\
\%\end{array}$ & $\underset{\%}{\text { Disagree }}$ & $\begin{array}{l}\text { Strongly } \\
\text { Disagree } \\
\%\end{array}$ & $\underset{\%}{\mathbf{N R}^{*}}$ & $\begin{array}{l}\text { Total } \\
100 \%\end{array}$ \\
\hline $\begin{array}{l}\text { It is important to me to speak Arabic } \\
\text { in all domains. }\end{array}$ & 18 & 39 & 29 & 12 & 2 & - & 100 \\
\hline $\begin{array}{l}\text { I prefer to use Arabic for instruction } \\
\text { at school. }\end{array}$ & 15 & 40 & 27 & 12 & - & 6 & 100 \\
\hline Arabic is more useful than Syriac. & 6 & 12 & 40 & 21 & 19 & 2 & 100 \\
\hline Arabic is a reflection of imperialism. & 9 & 5 & 30 & 41 & 11 & 4 & 100 \\
\hline $\begin{array}{l}\text { Arabic should be learned and used } \\
\text { everywhere because it is the official } \\
\text { language of the State. }\end{array}$ & 22 & 27 & 15 & 7 & 11 & 18 & 100 \\
\hline $\begin{array}{l}\text { Arabic is the prestigious language in } \\
\text { the state, so it is better to learn it. }\end{array}$ & 16 & 30 & 37 & 2 & 5 & 10 & 100 \\
\hline $\begin{array}{l}\text { Knowledge of Arabic is necessary } \\
\text { for success in my job. }\end{array}$ & 51 & 32 & 4 & 1 & - & 12 & 100 \\
\hline $\begin{array}{l}\text { Knowledge of Arabic made it } \\
\text { possible for me to advance } \\
\text { professionally. }\end{array}$ & 34 & 19 & 30 & 2 & 7 & 8 & 100 \\
\hline $\begin{array}{l}\text { Arabic is more important than Syriac } \\
\text { in my work. }\end{array}$ & 11 & 23 & 16 & 18 & 27 & 5 & 100 \\
\hline $\begin{array}{l}\text { Learning Arabic improves my } \\
\text { economic status. }\end{array}$ & 14 & 17 & 45 & 7 & 9 & 8 & 100 \\
\hline
\end{tabular}

*Key: NR=No Response

Results reported in Table 8 which show the respondents' view concerning the importance of using Arabic more than Syriac show that $34 \%$ of the respondents emphasize the importance of using Arabic in their work, $45 \%$ disagree, probably because some of them work in some Chaldo-Assyrian institutions and schools. Also, results show that $16 \%$ of the respondents are undecided and the rest of the responses are empty $5 \%$.

Table 8 also shows that $31 \%$ of the respondents agree that learning Arabic improves their economic status, $45 \%$ undecided and $16 \%$ of them disagree.

\section{DISCUSSION}

Results regarding the domains in which languages are used show that the Chaldo-Assyrians use the majority language (Arabic) and the minority ethnic language (Neo-Aramaic or Syriac) in different situations with different people and on different topics.

As indicated in Table 1 results reveal that a great number of Chaldo-Assyrian respondents use their mother tongue Syriac with their families at home. Moreover, they use Syriac predominantly and frequently with their fathers, mothers, siblings and other relatives face-to-face, on the phone or at family meetings. Only few of them $4 \%$ use both Arabic and Syriac at home domain. Probably, this indicates that the Chaldo-Assyrian families and relatives pass their ethnic language to their children as well. It is possible that parents, consciously, create an environment that nurtures ethnic language. In addition to that, the Chaldo-Assyrians may use their ethnic language at homes because they believe it is important for their children to learn it to reserve their ethnicity, traditions and religion values. This result is in line with Fishman (1991) who emphasizes the role of the family or home domain in maintaining the ethnic language. For the language to be maintained, it needs to be passed on to, and acquired by, each successive generation and it is often parents who decide to teach their mother tongue to their children.

Moreover, this result supports Clyne and Kipp (1999) who note that "home has been the key element of language maintenance, and if a language is not maintained in the home domain, then it cannot be maintained elsewhere." (p.47)

Results reported in Table 2, concerning language use in the neighborhood show that the Chaldo-Assyrian respondents use both languages Syriac and Arabic side by side with their friends and people in the neighborhood. However, some respondents believe that Arabic dominates the ethnic language Syriac when they buy vegetables in the neighborhood. 
This result can be explained by the fact that the majority of the respondents are in frequent contact with their Arab friends in Arab and in mixed Arab Chaldo-Assyrian neighborhoods. Consequently, Arabic is used side by side with Syriac or sometimes dominates it in some places where the Arabs are the majority. This result matches to a certain extent Fishman (1989) who discusses three resolutions that can be considered the outcome of languages in contact. The current result supports the third resolution where the indigenous minority language (i.e. Syriac) is used side by side with the majority language (i.e. Arabic); each language is used for different reasons and under different circumstances. Moreover, the result is in line with Rohani, Choi, Amjad, Burnett, \& Colahan (2005) who argue that the first main factor contributing either to language maintenance or shift is the family.

Results reported in Table 3 regarding language use at workplace indicate that the two languages are used together at the work domain. It is clear that the respondents' language choice at work with their fellow ethnic workers and bosses is Syriac. Other times, Arabic is predominant in use by the respondents at workplace probably because they work in mixed Arab Chaldo-Assyrian institutions like government and private institutions. This result supports Weinreich (1974) who believes that the usefulness of a language, its role in social advance, and its literary cultural value help in maintaining the ethnic language.

Results reported in Table 4 which show language use in the domain of religion (at Church) show that Syriac is dominating in praying and with celebrant and priest and in religious meetings outside the place of worship. This result suggests that the Chaldo-Assyrians value their language, Syriac, because they believe it is highly associated with their religion (Christianity) and thus they try to preserve it. Additionally they believe that they are the indigenous people and their language has existed for thousands of years prior to Arabic in Iraq and therefore they have the right to use it and keep it alive in their land. This result corroborates the idea of Schrauf's (1999) which asserts that religious practices are the most important indicators of language retention. Also, this finding is consistent with the results of Al-Nahar (2009) who concludes that the participants in her study use mainly Armenian in the church and in different other situations.

The study also reveals that a high percentage of the Chaldo-Assyrian respondents use both Syriac and Arabic for watching T.V. programs and listening to radio programs. In fact, mass media can also play an important role in using and preserving ethnic languages and cultures. There are many broadcasting television and radio stations that belong to the Chaldo-Assyrian community and consequently they have the chance to choose their ethnic language (Syriac) for such purposes. It indicates that broadcasting outlets which are owned by a number of Chaldo-Assyrian political parties preserve and support their language, culture and religion. Probably, the media represents an important means of communication with people and community and thus the language used in the media will be maintained. In addition to that, the number of Chaldo-Assyrians in the homeland, Iraq, more precisely in Baghdad, is larger than any other place outside of it (i.e. in the neighboring countries). This result is consistent with Fishman (1991) who describes the role of various ethnic institutions in language maintenance.

Results of language use in the domain of emotional and self-expression in Table 5 indicate that a high percentage of the Chaldo-Assyrian respondents use Syriac in expressing inner speech such as in dreaming and expressing happiness or anger. This result supports Fishman (1966) who emphasizes the importance of "psychological processes" in maintaining ethnic languages (p.424).

Results related to language attitudes indicate that the Chaldo-Assyrians in Baghdad express strong and positive opinions towards their ethnic language Syriac. They perceive Syriac as the most beautiful language. It is viewed as the prestigious and the national language, and the symbol of their ethnic identity. It associates them with their childhood, their heritage and history. Some of them consider Syriac more useful than Arabic and should be used in all domains. According to them, Syriac should be used officially side by side with Arabic at public schools. Perhaps, the positive attitudes towards their ethnic language stem from the deep and painful history through which they suffered discrimination and many other injustices. Hence, they rally around their language which actually represents the main constituents of their national identity. Their language is the symbol of their ethnicity. They believe that they are the original inhabitants of the land and they have the right to teach it in public schools and in many other domains. This finding supports Rohani et. al (2005) who have found that parents, both consciously and unconsciously, create an environment that nurtures or impairs heritage language acquisition in the framework of their attitudes towards languages.

According to them, Syriac is not dying in the Chaldo-Assyrian homes and community in Baghdad; this assumption is supported by the respondents' answers to the questions that asked about the use of Syriac at home; where the overwhelming majority asserts that Syriac is the dominant language in their homes with their family members. Perhaps, they believe that Syriac is a vehicle of a highly prized culture and religion that stems from their long history of suffering.

Moreover, they believe that their children must be able to communicate effectively in Syriac. This is perhaps due to psychological reasons because the Chaldo-Assyrians in Baghdad associate Syriac with their parents' roots and therefore want their children to be connected with their language psychologically too. Thus, the importance of Syriac stems from its psychological, emotional, and sentimental attachment with their childhood and parents' roots. This is in line with Weinreich (1974) who claims that "some ethnic groups stick to mother tongue because it becomes a symbol of group integrity, based on the extensive emotional involvement of the speakers with the language during the period of its acquisition in childhood."(p.100).

Results related to the attitudes of Chaldo-Assyrian respondents towards Arabic show that they use it because it is the official language of the State which is the most commonly used language everywhere in Iraq and therefore they use it predominantly in all official institutions and in many other public places. Having knowledge of Arabic is necessary for them as it makes them advance professionally and it is necessary too for succeeding in their jobs. However, some of them, 
$45 \%$, do not believe that Arabic is important in their work, probably because some of them work in some Chaldo-Assyrian institutions and schools and they see it not quite important for them to use Arabic there.

\section{CONCLUSIONS}

An analysis of the overall results of the study indicates that the Chaldo-Assyrians have used their ethnic language in a variety domains especially the home, the church and other inner speech. They have been relatively successful in maintaining their ethnic language despite of the long-term contact with many languages such as Arabic, Kurdish, Turkish and Persian. Results also have shown that the Chaldo-Assyrians in Baghdad have positive attitudes towards their ethnic language i.e. Syriac and towards Arabic. They perceive Syriac as the most beautiful language. It is viewed as the prestigious and the national language, and the symbol of their ethnic identity. It associates them with their childhood, their heritage and history. Moreover, their attitudes towards Arabic are somewhat positive and show that they use it equally since it is the official language of the State which is the most commonly used language everywhere in Iraq and therefore they use it predominantly in all official institutions and in many other public places.

\section{REFERENCES}

Al-Khatib, M. (2001). Language shift among the Armenians of Jordan. International Journal of Society and Language. 12.(5), 153-177.

Al-Nahar, R. (2009). Language maintenance among the Armenians of Jordan, (unpublished MA thesis), MEU, Amman: Jordan.

Bickerton, D.(1971). Inherent variability and variable rules. Foundations of Language.7, (4).457-492.

Butler, L.M. and DePhelps, C. (1994). Focus groups: A tool for understanding community perceptions and experiences. Community Ventures, Partnerships in Education and Research Series. Pullman, WA: Washington State University. Retrieved August 22, 2012 from http://http://wrdc.usu.edu

Clyne, M. \&Kipp, S. (1999). Pluricentric languages in an immigrant context: Spanish, Arabic, and Chinese. Berlin: Mouton de Gruyter.

Dweik, B. (1986) The language situation among three linguistic minorities in Jerusalem. In B. Dweik(Ed.), Research papers in applied linguistics (pp.47-66). Al-Khalil: Hebron University.

(2000).Linguistic and cultural maintenance among the Chechens of Jordan. Language, Culture and Curriculum, 13(2), 184-195

Fishman, J. (1966). Language loyalty in the United States. The Hague: Mouton and Co.

(1989).Language and ethnicity in minority sociolinguistic perspective. England: Multilingual Matters LTD.

(1991).Reversing language shift: Theoretical and empirical foundations of assistance to threatened languages.Clevedon: Multilingual Matters.

(2000). Who speaks what language to whom and when? In L.Wei (Ed.), The bilingualism reader, (pp. 82-99). London: Routledge. Retrieved May 5, 2012 from http:// www.books.google.jo

Friðriksson, F. (2008).Language change vs. stability in conservative language communities: A case study of Icelandic. (Doctoral thesis), University of Gothenburg,Göteborg: Sweden. Retrieved in January 19,2012 from http://hdl.handle.net

Hamers, J. \& Blanc, M. (1999). Bilinguality and bilingualism.Cambridge: Cambridge University Press.

Kittaneh, D. (2009). The language situation among the Arabs of Israel.(Unpublished MA thesis), MEU, Amman: Jordan.

McClure, E. (2001). Language and identity in the Assyrian diaspora. Studies in the Linguistic Sciences, 31(1), 107120.Retrieved December 16, 2011 from http://hd.handle.net.

Nofal, M. (2011). The language situation among the Indians of Yemen: A sociolinguistic study, (unpublished MA thesis), MEU, Amman: Jordan.

Odisho, E.Y. (1999). Assyrian language maintenance and erosion in U.S.: A world War I immigrant family case study. Journal of Assyrian Academic Studies, 8(1), 3-14. Retrieved December 18, 2011 from http://jaas.org.

Rohani, S., Choi, C., Amjad, R. N., Burnett, C., \&Colahan, C. (2005). Language maintenance and the role of family amongst immigrant groups in the United States: Persian-speaking Bahá'ís, Cantonese, Urdu, Spanish, and Japanese: An exploratory study. Retrieved May 5, 2012 fromhttp://www.tc.columbia.edu.

Schrauf, R. W. (1999). Mother tongue maintenance in North American ethnic groups.Cross-Cultural Research, 33, 175192. Retrieved May 5, 2012 from http://www.sagepub.com

Spolsky, B. (2001). Sociolinguistics. Oxford: Oxford University Press.

Thomason, S. (2001).Language contact. Edinburgh: Edinburgh University Press.

Vakhtin, N. (1998). Endangered languages in northeast Siberia: Siberian Yupik and other Languages of Chukotka. In : Erich Kasten (Ed.). Bicultural education in the north: Ways of preserving and enhancing indigenous peoples' languages and traditional knowledge, (pp. 159-173). Munster: Waxmann Verlag.. Retrieved in January 19, 2012 from http://siberian-studies.org

Von Gleich, U. \&Wolck W. (1994).Changes in language use and attitudes of Quechua-Spanish bilinguals in Peru. In: Cole, P. et al..,(Ed.): Language in the Andes, (pp.27-50). Newark, DE: University of Delware. Retrieved in January 19,2012 from http://books.google.com 
Weinreich, U. (1974). Languages in contact: Findings and problems. The Hauge: Mouton.

Winford, D. (2003). An introduction to contact linguistics. Oxford : Blackwell Publishing.

Wright, S, Holmes, H., \& Kelly, H. (1995).Languages in contact and conflict: Contrasting experiences in the Netherlands and Belgium. England: Clevedon. 